\title{
PELATIHAN PENULISAN PROPOSAL PENELITIAN TINDAKAN KELAS BAGI GURU SMA PATRA MANDIRI I PALEMBANG
}

\author{
Dessy Wardiah ${ }^{1}$, Liza Murniviyanti $^{2}$, Hetilaniar $^{3}$, Dian Nuzulia Armariena $^{4}$ \\ Program Studi Pendidikan Bahasa dan Sastra Indonesia Universitas PGRI Palembang \\ Email : dessywardiah77@gmail.com ${ }^{1}$, murniviyantiliza@gmail.com ${ }^{2}$, \\ heti_ardesya@yahoo.com ${ }^{3}$, dianarera@yahoo.com ${ }^{4}$
}

\begin{abstract}
Abstrak
Pelatihan ini bertujuan agar para guru-guru SMA Patra Mandiri I Palembang dapat membuat proposal penelitian tindakan kelas. Pelatihan ini dilakukan di SMA Patra Mandiri I Palembang dengan jumlah peserta sebanyak 35 orang. Kegiatan pelatihan ini merupakan pelatihan singkat yang dilakukan sebanyak satu kali pertemuan. Metode yang digunakan adalah metode ceramah, tanya jawab, diskusi dan praktek yang dibimbing/dipandu oleh tim PkM. Hasil yang diperoleh adalah bahwa para guru SMA Patra Mandiri I Palembang dapat membuat proposal penelitian tindakan kelas.
\end{abstract}

Kata Kunci: penelitian tindakan kelas.

\begin{abstract}
The aim of the workshop was to accomplished a classroom reaction research proposal for the teachers in SMA Patra Mandiri I Palembang. These workshop was performed in SMA Patra Mandiri I Palembang with 35 participants. The short workshop was performed in one meeting. The materials were delivered by the lecture method, discussion method and practice method. The workshop result was the teachers can design a classroom reaction research proposal.
\end{abstract}

\section{Keyword: classroom reaction research}

\section{Pendahuluan}

Berbagai permasalahan yang timbul saat proses pembelajaran dapat berasal dari berbagai faktor. Faktor yang paling utama dalam kesuksesan dalam menjalankan proses pembelajaran adalah sikap guru, metode pembelajaran, materi ajar, silabus, RPP, dan sebagainya. Namun, permasalahan yang terjadi di kelas hanya guru yang mengajar di kelas tersebut yang mengetahuinya. Dengan demikian, guru haruslah sesegera mungkin untuk mengatasi permasalahan tersebut sebelum berimbas kepada hasil belajar yang kurang maksimal.

Banyak hal yang dapat dilakukan para guru dalam menciptakan suasana kelas yang menyenangkan. Salah satunya dengan berinovasi dalam setiap proses pembelajaran di kelas. Langkah inovatif tersebut dapat dilihat dari pemahaman dan penerapan guru tentang Penelitian Tindakan Kelas (PTK). PTK sangat mendukung program peningkatan pembelajaran di sekolah yang muaranya adalah peningkatan kualitas pendidikan. Hal ini, karena dalam proses pembelajaran, guru adalah praktisi teoritis yang sangat menentukan. Peningkatan kualitas pembelajaran merupakan tuntutan logis dari perkembangan ilmu pengetahuan, teknologi dan seni (IPTEKS) yang semakin pesat. Perkembangan IPTEKS mengisyaratkan penyesuaian dan peningkatan proses pembelajaran secara berkesinambungan, sehingga berdampak positif terhadap 
peningkatan kualitas lulusan dan keberadaan sekolah tempat guru mengajar.

Berdasarkan penjelasan tersebut, peningkatan kompetensi guru merupakan tanggung jawab moral bagi guru di sekolah. Peningkatan kompetensi guru mencakup empat jenis yaitu (1) kompetensi pedagogi, (2) kompetensi profesional, (3) kompetensi sosial, (4) kompetensi kepribadian. Berdasarkan Undang-Undang RI Nomor 20 tahun 2003 tentang Sistem Pendidikan Nasional, Peraturan Pemerintah RI Nomor 19 tahun 2005 tentang Standar Nasional Pendidikan dan Undang-Undang RI Nomor 14 tahun 2005 tentang Guru dan Dosen. Peningkatan kompetensi guru menjadi isu strategis dalam rangka peningkatan mutu pendidikan.

Bahkan menurut Peraturan Pemerintah RI Nomor 19 tahun 2005 tersebut pada pasal 31 ditegaskan, bahwa selain kualifikasi, guru-guru sebagai tenaga pendidik juga dituntut untuk memiliki sertifikat kompetensi sesuai dengan tingkat dan bidang keahlian yang diajarkan.

Penelitian tindakan kelas ini dapat meningkatkan kualitas pembelajaran, dapat mengembangkan keprofesionalan guru, juga dapat meningkatkan hasil belajar siswa. Hal ini sejalan dengan pendapat Rahdiyanta (2012) yang menyatakan bahwa PTK adalah merupakan suatu kegiatan penelitian yang bertujuan untuk membenahi dan mengatasi berbagai masalah dalam proses pembelajaran. Menurut Surya Dharma (2008:7) tujuan khusus PTK adalah untuk mengatasi berbagai persoalan nyata guna memperbaiki atau meningkatkan kualitas proses pembelajaran di kelas. Selain itu Surya Dharma (2008:8) juga mengatakan melalui PTK dapat menumbuhkembangkan kebiasaan, budaya, dan atau tradisi meneliti dan menulis artikel ilmiah di kalangan pendidik.

Penjelasan-penjelasan teoritis tersebut mengindikasikan bahwa pemahaman dan penerapan PTK akan membantu guru untuk mengembangkan keempat kompetensi yang dipersyaratkan oleh Undang-undang RI Nomor 14 tahun 2005. PTK akan memfasilitasi guru untuk meningkatkan kompetensi-kompetensi profesional, pedagogi, kepribadian dan sosial.

Melalui hasil wawancara informal dengan guru, maka dapat diketahui bahwa guru sekolah dasar maupun sekolah menengah jarang melakukan PTK. Salah satu alasannya bahwa guru sibuk memberi pelajaran sehingga tidak punya waktu untuk melakukan PTK. Walaupun kenyataannya guru harus melakukan PTK paling tidak untuk naik pangkat ke 4b. Oleh karena itu Dosen Program Studi Pendidikan Bahasa dan Sastra Indonesia FKIP Universitas PGRI Palembang melaksanakan pelatihan PTK bagi guru-guru SMA Patra Mandiri I Palembang

\section{Bahan dan Metode Pelaksanaan}

Kegiatan pengabdian kepada masyarakat ini dilaksanakan pada hari Kamis, 26 April 2018 di SMA Patra Mandiri I Palembang, dengan alamat J1. Kelapa Sawit, Komperta, Kec. Plaju, Kota Palembang, Sumatera Selatan 30268. Kegiatan pengabdian ini dilaksanakan sebanyak 1 (satu) kali tatap muka dengan rincian sebagai berikut.

Tabel 1 Waktu Pelaksanaan

\begin{tabular}{|c|l|l|l|l|}
\hline No & Waktu & Materi & Penyaji & Kegiatan \\
\hline 1 & $10.30-$ & Bab I & Dr. & Pemateri \\
& 10.45 & dalam & Dessy & memaparkan \\
& & PTK & Wardiah, & tentang \\
& & & M.Pd. & pengertian \\
& & & & PTK dan Hal \\
\hline
\end{tabular}




\begin{tabular}{|c|c|c|c|c|}
\hline No & Waktu & Materi & Penyaji & Kegiatan \\
\hline & & & & $\begin{array}{l}\text { yang ada } \\
\text { dalam Bab I } \\
\text { PTK }\end{array}$ \\
\hline 2 & $\begin{array}{l}10.45- \\
11.00\end{array}$ & $\begin{array}{l}\text { Bab II } \\
\text { dalam } \\
\text { PTK }\end{array}$ & $\begin{array}{l}\text { Liza } \\
\text { Murniviy } \\
\text { anti, } \\
\text { M.Pd. }\end{array}$ & $\begin{array}{l}\text { Pemateri } \\
\text { memaparkan } \\
\text { tentang hal- } \\
\text { hal yang } \\
\text { terdapat } \\
\text { dalam Bab II } \\
\text { PTK (Teori } \\
\text { yang } \\
\text { mendukung) }\end{array}$ \\
\hline 3 & $\begin{array}{l}11.00- \\
11.15\end{array}$ & $\begin{array}{l}\text { Bab } \\
\text { III } \\
\text { dalam } \\
\text { PTK }\end{array}$ & $\begin{array}{l}\text { Hetilania } \\
\text { r, MPd. }\end{array}$ & $\begin{array}{l}\text { Pemateri } \\
\text { menjelaskan } \\
\text { tentang } \\
\text { metodologi } \\
\text { penelitian } \\
\text { PTK (Bab } \\
\text { III) }\end{array}$ \\
\hline 4 & $\begin{array}{l}11.15- \\
11.30\end{array}$ & $\begin{array}{l}\text { Bab } \\
\text { IV } \\
\text { dan V } \\
\text { dalam } \\
\text { PTK }\end{array}$ & $\begin{array}{l}\text { Dian } \\
\text { Nuzulia } \\
\text { Armarien } \\
\text { a, M.Pd. }\end{array}$ & $\begin{array}{l}\text { Pemateri } \\
\text { menjelaskan } \\
\text { tentang hasil } \\
\text { penelitian, } \\
\text { simpulan } \\
\text { dan saran } \\
\text { (Bab IV dan } \\
\text { V) }\end{array}$ \\
\hline 5 & $\begin{array}{l}11.30- \\
12.00\end{array}$ & $\begin{array}{l}\text { Disku } \\
\text { si }\end{array}$ & $\begin{array}{l}\text { Pemateri } \\
\text { dan } \\
\text { Peserta }\end{array}$ & $\begin{array}{l}\text { Peserta } \\
\text { diberi } \\
\text { kesempatan } \\
\text { untuk } \\
\text { bertanya } \\
\text { tentang } \\
\text { materi yang } \\
\text { telah } \\
\text { disampaikan }\end{array}$ \\
\hline 6 & $\begin{array}{l}12.00- \\
13.00 \\
\end{array}$ & \multicolumn{3}{|c|}{ ISHOMA } \\
\hline 7 & $\begin{array}{l}13.00- \\
16.00\end{array}$ & $\begin{array}{l}\text { Pembi } \\
\text { mbing } \\
\text { an } \\
\text { Propo } \\
\text { sal } \\
\text { PTK }\end{array}$ & $\begin{array}{l}\text { Semua } \\
\text { Pemateri }\end{array}$ & $\begin{array}{l}\text { Peserta } \\
\text { dibimbing } \\
\text { oleh } \\
\text { pemateri } \\
\text { dalam } \\
\text { penyusunan } \\
\text { proposal } \\
\text { PTK }\end{array}$ \\
\hline
\end{tabular}

Peserta kegiatan pengabdian kepada masyarakat ini adalah adalah guru-guru SMA Patra Mandiri I Palembang yang berjumlah 35 orang. Metode yang digunakan adalah metode ceramah, tanya jawab, diskusi dan praktek yang dibimbing/ dipandu oleh tim PkM. Adapun tahapan yang dilakukan adalah sebagai berikut.

1. Tahap Presentasi

Pada tahap presentasi, setiap penyaji diberi waktu 15 menit untuk memaparkan materi tentang bagianbagian Penelitian Tindakan Kelas (PTK). Keempat orang penyaji secara bergantian menjelaskan materi yang telah dibagi pada tahap persiapan.

2. Tahap Diskusi

Setelah semua pemateri menyajikan materinya masing-masing, para peserta yang dalam hal ini guru-guru SMA Patra Mandiri $01 \quad$ Palembang diberi kesempatan untuk bertanya tentang materi yang telah disampaikan.

3. Tahap Pembuatan Proposal

Pada tahap ini, peserta diberi kesempatan untuk membuat proposal penelitian tindakan kelas yang dibimbing oleh pemateri. Tahap awal, guru diberi kesempatan untuk mengingat permasalahan di kelas dan mencatatnya dalam bentuk pernyataan. Tahap kedua, pemateri membimbing peserta mengubah permasalahan guru di kelas dalam bentuk judul Penelitian Tindakan Kelas dan rumusan masalahnya. Tahap ketiga, peserta mulai menggali latar belakang terjadinya permasalahan yang muncul di dalam kelas. Tahap selanjutnya, peserta dengan bimbingan pemateri menyusun proposal lengkap mulai latar belakang, masalah, tujuan, manfaat, landasan teori, hingga metodologi penelitian. 


\section{Hasil dan Pembahasan}

Berdasarkan hasil pengamatan selama kegiatan pengabdian kepada masyarakat ini berlangsung diperoleh hasil sebagai berikut :

a) Peserta pelatihan mengikuti workshop dengan sangat antusias.

b) Jika ada yang belum dimengerti, maka peserta mengajukan pertanyaan.

c) Peserta telah memahami konsep PTK dan alur penelitiannya, mulai dari perencanaan, pelaksanaan, evaluasi, dan refleksi.

d) Peserta sudah menemukan masalah di kelasnya masing-masing dan dapat merumuskan masalah serta telah membuat program perbaikan.

e) Peserta telah mampu melakukan evaluasi dan refleksi sehingga melakukan perbaikan pada bagian yang belum tercapai dengan maksimal.

f) Peserta sangat antusias dalam pembuatan proposal. Hal ini dapat dilihat dari judul dan masalah PTK yang mereka buat sudah bagus. Selain itu, peserta mengajukan pertanyaan tentang pengembangan masalah yang dihadapi di kelas untuk dijadikan sebuah proposal penelitian.

Penelitian Tindakan Kelas (PTK) merupakan jenis penelitian yang bertujuan untuk mengatasi masalah yang terjadi di kelas sehingga dapat meningkatkan kualitas pembelajaran di kelas. Hal ini seiring dengan pendapat Jaedun (2008), penelitian tindakan kelas PTK adalah salah satu jenis penelitian tindakan yang dilakukan oleh guru untuk meningkatkan kualitas pembelajaran dikelasnya (metode, pendekatan, penggunaan media, teknik evaluasi dsb).

Penelitian Tindakan Kelas juga bersumber dari permasalahan guru di kelas baik bersumber dari siswa, guru, metode, atau bahkan sumber pembelajaran. Hal ini didukung oleh Sukanti (2008), penelitian tindakan kelas adalah penelitian yang dilaksanakan berdasarkan permasalahan yang dijumpai guru dalam kegiatan pembelajaran. Penelitian tindakan kelas adalah suatu kegiatan penelitian yang berkonteks kelas yang dilaksanakan untuk memecahkan masalah-masalah pembelajaran yang dihadapi oleh guru, memperbaiki mutu dan hasil pembelajaran dan mencobakan hal-hal baru dalam pembelajaran demi peningkatan mutu dan hasil pembelajaran. Penelitian tindakan kelas dapat dilakukan secara individu maupun kolaboratif (Widayati, 2008).

$$
\text { Menurut Tim Unesa (2013:162) }
$$
Manfaat PTK bagi guru antara lain sebagai berikut. a) PTK dapat dijadikan masukan untuk memperbaiki pembelajaran yang dikelolanya; b) Guru dapat berkembang secara profesional, karena dapat menunjukkan bahwa ia mampu menilai dan memperbaiki pembelajaran yang dikelolanya melalui PTK; c) PTK meningkatkan rasa percaya diri guru; d) PTK memungkinkan guru secara aktif mengembangkan pengetahuan dan keterampilan. Selain bermanfaat buat guru PTK juga bermanfaat bagi siswa yaitu dapat meningkatkan proses dan hasil belajar siswa.

\section{Simpulan}

Penelitian Tindakan Kelas (PTK) sangat bermanfaat bagi siswa, guru, dan sekolah dalam meningkatkan hasil pembelajaran di kelas. Selain itu PTK juga dapat 
menunjukkan keprofesionalan guru dalam mengevaluasi hasil pembelajaran dan mengetahui permasalahan yang dihadapinya di kelas sehingga guru tersebut dapat melakukan perbaikan dalam meningkatkan mutu lulusan.

\section{Daftar Pustaka}

Dharma, S. (2008). Penelitian Tindakan Kelas. Direktorat Tenaga Kependidikan Direktorat Jenderal Peningkatan Mutu Pendidik Dan Tenaga Kependidikan Departemen Pendidikan Nasional

Jaedun, A. (2008). Prinsip-prinsip Penelitian Tindakan. Makalah Pelatihan PTK Bagi Guru Di Propinsi DIY. Lembaga Penelitian UNY. 2008.

Rahdiyanta, D. (2012). Penelitian Tindakan Kelas (Pengertian, Prinsip, Dan Karakteristik Ptk). Makalah disampaikan pada Seminar Penelitian Tindakan Kelas Bagi Guru SMK yang diselenggarakan oleh Fakultas Teknik Universitas Negeri Yogyakarta pada tanggal 12 Juli 2012.

Sukanti. (2008). Meningkatkan Kompetensi Guru Melalui Pelaksanaan Penelitian Tindakan Kelas. Jurnal Pendidikan Akuntansi Indonesia. Vol. VI. No. 1. Tahun 2008.

Tim Unesa, (2013). Modul PLPG Pendidikan Ekonomi. Konsorsium Sertifikasi Guru

Widayati, A. 2008. Penelitian Tindakan Kelas. Jurnal Pendidikan Akuntansi Indonesia Vol. VI No. 1 - Tahun 2008 Hal. 87 - 93 